\title{
Sodyumlu Sulama Sularının Toprak Tuzluluk Değișimine Etkisi
}

\author{
Ayșe ERTAȘ PEKER' $\quad$ Hasan Sabri ÖZTÜRK²*
}

'Karadeniz Tarımsal Araștırma Enstitüsü Müdürlüğü, Samsun

${ }^{2}$ Ankara Üniversitesi, Ziraat Fak, Toprak Bilimi ve Bitki Besleme Bölümü, Ankara

\begin{abstract}
*Sorumlu yazar e-mail (Corresponding author e-mail): hozturk@agri.ankara.edu.tr
Geliș tarihi (Received) : 03.04.2020

Kabul tarihi (Accepted): 08.08.2020

DOI: $10.21657 /$ topraksu.713951
\end{abstract}

\section{Öz}

Sodyum içeren sulama sularının kullanımı, toprakların sodyum içeriklerinin artmasına neden olmaktadır. Bu çalıșmada, $\mathrm{Na}^{+}$içeren sulama sularının kullanımı sonucunda, topraktaki $\mathrm{pH}$ ve EC değerlerinin izlenmesi amaçlanmıștır. Deneme tarla koșullarında, üç tekerrürlü ve beș uygulama olacak șekilde yürütülmüștür. EC değerleri $<3 \mathrm{dS} \mathrm{m}^{-1}$ 'den düșük olan 20 ve 40 SAR değerlerindeki sular $\mathrm{NaCl}$ ve $\mathrm{NaHCO}_{3}$ tuzlarından yapay olarak hazırlanmıș ve damla sulama yöntemi ile uygulanmıștır. Deneme süresince on beș sulama yapılmıș ve her beș yıkama sonrası alınan toprak örneklerinde belirtilen toprak tuzluluk parametrelerinin değișimi izlenmiștir. NaCl uygulamalarının her iki dozunda da toprak $\mathrm{PH}_{\mathrm{e}}$ 'sının 2. dönem sonuna kadar önemli düzeyde artmadığı, hatta 2. dönem süresince sadece SAR 20 uygulamasında önemli düzeyde azaldığı ve sulama öncesi döneme benzer sonuçların olduğu, sadece kıș yağıșlarından sonra 3. dönemden itibaren $\mathrm{pH}_{e}$ 'nın artmaya bașladığı belirlenmiștir. SAR 40 sulama suyu uygulamasında, $\mathrm{NaHCO}_{3}$ tuzu toprak pH'sını 4. periyodun sonunda 8.28'e yükseltirken, $\mathrm{NaCl}$ tuzu toprak pH'ını 7.65'e yükseltmiștir. Toprak yüzeyinde ve alt katmanlarda EC e değerlerinin özellikle NaCl'lü suyun kullanıımasıyla, her iki tuz çeșidinde de SAR daki artıșa paralel olarak arttığı belirlenmiștir. Ayrıca 2. ve 3. dönem arasında kıș yağıșlarının etkisiyle tuzların üst toprak katmanından alt katmanlara tașındığı tespit edilmiștir. Bașlangıç dönemindeki ortalama toprak $\mathrm{EC}_{\mathrm{e}^{\prime}}$ değeri $0.60 \mathrm{dS} \mathrm{m}^{-1}$, NaCl uygulamasının SAR 40 dozunda 4.dönem sonunda 0-10 cm toprak derinliğinde $5.53 \mathrm{dS} \mathrm{m}^{-1}$ e ulașmıștır. Sonuç olarak $\mathrm{PH}_{\mathrm{e}}$ 'nın değișik SAR değerlerine sahip sulama sularının deneme süresince yapılan on beș sulama sonrasında toprakların tamponlama özelliğinden dolayı belirgin olarak değișmediği, sulama suyu tuzluluğuna bağlı olarak EC 'nin değișiminde sulama dönemleri arasında istatistiksel olarak farklııkların olduğu belirlenmiștir.

Anahtar Kelimeler: Sodyum, SAR, pH, EC, sulama, toprak tamponluğu

\section{Effect of Sodic Irrigation Water on Soil Salinity Changes}

\begin{abstract}
The use of sodium-containing irrigation water causes to increase the sodium content of soils. In this study, it was aimed to monitor soil $\mathrm{pH}$ and $\mathrm{EC}$ values as a result of the application of irrigation waters containing $\mathrm{Na}^{+}$. Field trial was conducted with three replicates and five treatments. Artificial irrigation waters of 20 and 40 SAR with ECs are less than $3 \mathrm{dS} \mathrm{m}^{-1}$ were prepared from $\mathrm{NaCl}$ and $\mathrm{NaHCO}_{3}$ salts separately and applied to the parcels by drip irrigation. A total of fifteen irrigation applications were performed, and soil salinity parameters were monitored from the samples taken in every five watering.

* Bu çalıșma Ankara Üniversitesi Fen Bilimleri Enstitüsü tarafından kabul edilen Ayșe ERTAS PEKERe ait "Tuzlu sulama sularının kullanımına bağlı olarak toprak fiziksel ve hidrolojik özelliklerindeki değișimin izlenmesi " isimli Doktora Tez çalıșmasının bir bölümünden üretilmiștir.
\end{abstract}

Hasan Sabri Öztürk: https://orcid.org/0000-0002-0106-6939

Ayșe Ertaș Peker'in: https://orcid.org/000-0003-1385-2125 
It was determined that the soil $\mathrm{pH}_{\mathrm{e}}$ did not increase significantly in both doses of $\mathrm{NaCl}$ applications until the end of the 2 nd period, even decreased significantly in only SAR 20 applications during 2 nd period and had similar results to the pre-irrigation period, and the $\mathrm{pH}_{\mathrm{e}}$ started to increase only after the third period after the winter rains. Similarly, the soil $\mathrm{pH}_{\mathrm{e}}$ of $\mathrm{NaHCO} 3$ applications did not change until the end of 2nd period, and by 3nd periods, there were increases for both doses, especially for SAR 40. While the $\mathrm{pH}$ of soil with $\mathrm{NaHCO}_{3}$ salt reached to 8.28 after the 4th period, $\mathrm{NaCl}$ salt increased the soil $\mathrm{pH}$ to 7.65 in SAR 40 irrigation water treatment. The $\mathrm{EC}_{\mathrm{e}}$ values both on the soil surface and subsurface increased in harmony with the increase in SAR for both salt types, especially with the use of water with $\mathrm{NaCl}$. In addition, the salts were transported from the upper soil layer to the lower layers by winter rains between the 2 nd and 3 nd periods. The use of irrigation water containing $\mathrm{NaHCO}_{3}$ salt had no significant effect on soil EC values. The average the initial soil $\mathrm{EC}_{e}$ of $0.60 \mathrm{dS} \mathrm{m}^{-1}$ reached to $5.53 \mathrm{dS} \mathrm{m}^{-1}$ in the SAR 40 of $\mathrm{NaCl}$ application at $0-10 \mathrm{~cm}$ soil depth at the end of the 4 th period. As a result, the soil $\mathrm{pH}_{\mathrm{e}}$ has not changed significantly due to the buffering capacity of the soils, with the use of irrigation waters with different SAR values for a medium period of time. EC $C_{e}$ values on the soil surface increased especially in $\mathrm{NaCl}$ applications due to the increase of SAR values of the waters, except for the 3nd periods.

Keywords: Sodium, SAR, pH, EC, irrigation, soil buffering capacity,

\section{Giriș}

Toprak ve su kaynaklarının etkin kullanımı ve sürdürülebilir yönetiminin önemi gittikçe artmaktadır. Tarımda kullanılabilir özellikteki suya erișimin mümkün olmadığı durumlarda, var olan düșük kalitedeki su kaynaklarının sulamada kullanabilir hale getirmenin yolları aranmaktadır. $\mathrm{Bu}$ bağlamda sulama suyunda bașta $\mathrm{Na}^{+}$içeren tuzlar olmak üzere tuzların, toprağa ve bitkilere olan etkilerinin tuzların farklı konsantrasyonları ve cinsleri yönünden ele alınması gerekliliğini ortaya çıkmıștır.

Sulama, bitkininin intiyaç duyduğu ve yağıșlarla karșılanamayan suyun toprakta bitkinin kök bölgesine gerektiği miktar ve zamanda verilmesidir. Sulama suyu kalitesini belirleyen parametreler genel olarak; çözünebilir tuzların toplam konsantrasyonu, sodyum iyonunun diğer katyonlara nisbi oranı, bor gibi bazı zararlı olabilecek özel elementlerin konsantrasyonları, bazı koșullarda kalsiyum ve magnezyum konsantrasyonu ile ilgili olarak bikarbonat konsantrasyonlarıdır.

Sulama suyunun arzu edilmeyen özellikleri bitki gelișmesini doğrudan ve dolaylı olarak etkilemektedir. Sulama suyunun bitki gelișmesine doğrudan etkileri ya bitki öz suyundan yüksek ozmotik koșulların yaratılması ya da suda bitkilere zararlı bileșiklerin bulunması nedeniyle ortaya çıkmaktadır (Kurunç, 2017). Dolaylı olarak etkisi ise sulama suyunun kalitesinin toprağa etki yapması șeklinde olmaktadır.

İnorganik ve organik kompleks bileșiklerden olușan toprak, sulama suyunda bulunan bileșiklerle hem fiziksel hem de kimyasal olarak reaksiyona girer. Suyun kalitesini ortaya çıkaran bu bileșiklerle toprak kompleksleri arasında meydana gelen reaksiyonlar sonucu bazı toprak özellikleri etkilenmektedir. Örneğin sulama suyunda $\mathrm{Ca}^{+2}$ iyonlarının bulunması, toprağın fiziksel özelliklerinden hava ve su geçirgenliğinin düzenlenmesine neden olduğu halde $\mathrm{Na}^{+}$iyonlarının bulunması tamamen aksi durumun ortaya çıkmasına neden olmaktadır. Toprakların fiziksel özellikleri genellikle toprakların kimyasal bileșimleri ile yakından ilgili bulunmaktadır. Toprağın infiltrasyon hızı, hava ve su geçirgenliği, toprak strüktürü, gözenek miktarı ve gevșekliği gibi toprağın bazı fiziksel özelliklerinin toprağın kimyasal bileșimine bağı olarak değiștiği yapılan bazı araștırmalar sonucunda ortaya çıkmıștır. Sulama suyu kimyasal bileșimi üzerinde etkili olduğundan su kalitesi ile toprak arasında yakın ilișki bulunmaktadır.

Sulamada kullanılan sular, içerdikleri tuzların cins ve miktarına bağlı olarak çok değișik özellikte olabilirler. Tuzlar kayaların ve toprak zerrelerinin ayrıșma ve parçalanma olayları ile olușurlar Bunlar içerisinde kireç, jips ve diğer yavaș ayrıșabilen toprak mineralleri vardır. Ayrıșan tuzlar, sularla arazilere tașınarak bitki kök bölgesinde birikirler. Biriken tuzlar eğer kök bölgesinden yağıș veya yıkamalar ile uzaklaștırılamaz ise zamanla toprakta tuzluluk sorunu olușması muhtemeldir (Sönmez ve Beyazgül, 2008).

Sulama suyunda $\mathrm{Na}^{+}$bulunması durumunda, bu elementin toprak kolloidleri tarafından adsorbe 
edilmesi ve sonuçta da agregatların parçalanması gerçekleșmektedir. (Rhoades ve Ingvalson, 1969; Rowell vd. 1969; Felhendler vd. 1974; Frenkel vd.1978; Pupisky ve Shainberg, 1979; Shainberg vd. 1981 a,b; Shainberg ve Levy, 1992; Amezketa, 1999). Özdemir (1998), Na+ ile doygun olan toprakların Ca+2 ile doymuș topraklardan daha fazla hidrate ve dispers olduğunu ve toprak agregatlarını parçalayarak toprak strüktürünü bozduğunu $\mathrm{Ca}^{+2}$ un ise toprak tanelerini kümeleștirici etkisinden dolayı agregat olușumunu teșvik edici olduğunu belirtmiștir. Sulama suları ile verilen $\mathrm{Na}^{+}{ }^{\prime}$ un toprakta birikmesi ile $\mathrm{pH}$, doygun hidrolik iletkenlik, değișebilir $\mathrm{Na}^{+}$, sodyum adsorbsiyon oranı (SAR), saturasyon ekstraktı elektriksel iletkenlik $\left(E C_{e}\right)$, değișebilir sodyum yüzdesi (ESP) ve yarayıșlı toprak suyu içeriği (AWC) gibi toprakların birçok fiziko-kimyasal özellikleri değișmektedir (Al-Busaidi ve Cookson, 2003). Düșük kaliteli sulama sularının toprağa uygulanması, toprakta mevcut olan katyon ve anyonlar arasındaki dengenin bozulmasına, zararlı bileșiklerin birikimine, tuz miktarlarında artıșlara ve toprak pH'sında düșüșlere veya artıșlara neden olmaktadır (Çakır vd. 1997).

Makoi ve Verplancke (2010), çalıșmalarında sodyumlu toprakların fazla miktarda çözünebilir tuz içermelerinden (özellikle Na2SO4 ve $\mathrm{NaCl}$ ) dolayı dünyada çok ciddi çevresel sorunlara neden olduğunu belirtmișlerdir. Sulama suyu tuzluluğuna bağlı olarak toprak pH sının artmasına (Mancino ve Pepper, 1992; Schipper vd. 1996; Hassanli vd.2008; Tarchouna vd. 2010) olduğu gibi toprak $\mathrm{pH}$ sının azalmasına ait (Wang vd. 2011; Sun vd. 2012; Li vd. 2015; Li vd. 2019) çalıșmalarda bulunmaktadır.

Bu çalıșmada, $\mathrm{Na}^{+}$içeren iki farklı tuz çeșidi ( $\mathrm{NaCl}$ ve $\mathrm{NaHCO}_{3}$ ) ile hazırlanan sulama sularının deneme süresince yapılan on beș sulama ile uygulanmasının, toprakta $\mathrm{pH}$ ve EC gibi bazı toprak özelliklerine olan etkisinin incelenmesi amaçlanmıștır.

\section{MATERYAL VE YÖNTEM}

Çalıșma 2017-2018 yılları arasında Ankara Üniversitesi Haymana Araștırma ve Uygulama Çiftliğinde, tesadüf blokları deneme desenine göre 3 tekerrürlü ve 5 uygulama konulu olarak kurulan deneme alanında yürütülmüștür. Denemede parseller 3x4m boyutlarında hazırlanıp, bloklar arası ve parseller arası 2 m boșluk bırakılmıștır. EC değeri <3 dS $\mathrm{m}^{-1}$ 'den daha düșük olacak șekilde ve SAR değeri 0 (kontrol) , 20 ve 40 olan iki farklı doz ve iki farklı tuz çeșidi ( $\mathrm{NaCl}$ ve $\mathrm{NaHCO}_{3}$ ) ile hazırlanan sulama suları kullanılmıștır. Denemede sulama suyu kaynağı olarak İkizce Gölet'inden çiftliğe iletilen su kullanılmıstır. Sulama suyunun hazırlanmasında kullanılacak tahmini iyon konsantrasyonları Extract Chem Sofware programı ile hesaplanmıștır. Hazırlanan tuzlu sular, damla sulama yöntemi ile deneme desenine göre tarla kapasitesi değerinin \%25 fazlası olacak șekilde parsellere verilmiș, solma noktasına kadar beklenip aynı tuzlu su ile sulamalara devam edilmiștir. Çalıșmanın ilk yılında her dönemde 5 er sulama olacak șekilde 10 sulama yapılmıștır (1. ve 2.dönem). Sulamaları takip eden kıș mevsimi boyunca parsellerde tuzlu su uygulaması yapılmamıștır (3.dönem). Kıș sonrasında 5 sulama daha yapılmıștır (4.dönem). Dört dönemde 0-10, 10-20 ve $20-30 \mathrm{~cm}$ derinlikten toplam 90 adet bozulmuș toprak örneği alınmıștır. Sulama uygulamaları ile toprak örneklerinin alındığı yapıldığı zamanlar Çizelge l'de verilmiștir. Çalıșma bașlangıcında deneme alanının dıșından alınan üç farklı derinlikten (0-10, 10-20 ve 20-30 cm) ve tuzlu su uygulaması yapılan tüm parsellerden alınan toprak örneklerinden Bouyoucous (1951)' in geliștirmiș olduğu hidrometre metodu ile mekanik analizleri yapılarak kum, silt ve kil yüzdeleri bulunmuștur. Toprak örneklerinin bünye sınıfları ise bünye üçgeninden yararlanılarak belirlenmiștir (Akalan, 1977). Toprak reaksiyonu $\left(\mathrm{pH}_{\mathrm{e}}\right)$ ve elektriksel iletkenlik $\left(\mathrm{EC}_{\mathrm{e}}\right)$ saturasyon ekstraktında (Richards, 1954), kireç (CaCO3) Scheibler kalsimetresiyle volümetrik (Richards, 1954), organik madde modifiye edilmiș WalkleyBlack yaș yakma (Nelson ve Sommers, 1982), katyon değișim kapasitesi sodyum asetat çözeltisi

Çizelge 1. Sulama ve toprak örneklerinin alınma zamanları

Table 1. Application times of irrigation and taking soil samples Toprak

\begin{tabular}{ccc} 
Dönem & Sulama zamanı & $\begin{array}{c}\text { örneklerinin } \\
\text { alınma zamanı }\end{array}$ \\
\hline 1 (Beș sulama & 17.05.2017-05.07.2017 & $\begin{array}{c}26.07 .2017- \\
28.07 .2017\end{array}$ \\
\hline $\begin{array}{c}\text { sonrası) } \\
\text { (On sulama } \\
\text { sonrası) }\end{array}$ & $29.07 .2017-03.10 .2017$ & $\begin{array}{c}19.10 .2017- \\
22.10 .2017\end{array}$ \\
\hline
\end{tabular}

15.05.2018-

3 (Kıș sonrası) 17.05.2018- Kıș sonrası toprak örneklemesi

4 (Kıș sonrası $18.05 .2018-26.08 .2018$ 18.09.2018- 
$(\mathrm{pH} 8.2)$ ile muamele edilerek flamefotometrede (Bower vd. 1952) belirlenmiștir.

Farklı tuz konsantrasyonlarında hazırlanan sulama sularının farklı dönemlerde uygulanması sonucunda, sulama suyu dozu, tuz çeșidi ve toprak derinliği değișkenlerinin toprak özelliklerindeki değișimi ortaya koymak için, çoklu değișkenlik istatistik yöntemlerinden MANOVA (Multiple ANOVA), sulama dönemleri arasında farklılıklar one-way ANOVA ile belirlenmiș, ardından farklılıkların önemli olduğu durumlar için post-hock sInıflama testlerinden TUKEY testleri SPSS 20.0 paket programı kullanılarak yapılmıștır.

\section{BULGULAR VE TARTIȘMA}

Çalıșma alanı topraklarının bazı özelliklerine ilișkin sonuçlar Çizelge 2 ' de verilmiștir. Toprakların 0-10, 10-20 ve 20-30 cm derinliklerinde kil içeriği \%57.88-59.26 arasında değișmektedir ve killi tın bünyeye sahiptir. $\mathrm{pH}_{\mathrm{e}} 0-10,10-20$ ve 20$30 \mathrm{~cm}$ derinliklerinde 7.55 ile 7.61 arasında değișim göstermektedir. Ortalama $\mathrm{pH}_{\mathrm{e}}$ değeri 7.57 olan çalıșma alanı toprakları hafif alkali olarak değerlendirilmiștir. $\mathrm{EC}_{\mathrm{e}}$ ise ortalama 0.50 ile $0.70 \mathrm{dS} \mathrm{m}^{-1}$ arasında değișmekte olup tuzsuz sınıfına girmektedir. OM içeriği ise 0-10, 10-20 ve 20-30 cm derinliğinde \%0.91-1.55 arasında değișmekte olup ortalama \%1.23 değerine sahip olan topraklar organik madde açısından az șeklinde sınıflandırımaktadır. Çalıșma alanında derinliğe bağlı olarak organik maddenin azaldığı görülmektedir. Toprakta çoğunlukla bașat kil mineralince belirlenen KDK ise 0-10, 10-20 ve 20-
Çizelge 2. Çalıșma alanı topraklarının bazı Özellikleri ( $N=12)$ Table 2. Some features of working area soils $(N=12)$

\begin{tabular}{lcccc}
\hline \multicolumn{5}{c}{ Toprak Derinliği $(\mathrm{cm})$} \\
\hline Toprak özellikleri & $0-10$ & $10-20$ & $20-30$ & Ort \\
Bünye sınıfı & Killi tın & Killi tın & Killi tın & \\
Kum, \% & 27.72 & 28.85 & 30.54 & 29.03 \\
Kil. \% & 57.88 & 58.34 & 59.26 & 58.49 \\
Silt ,\% & 14.40 & 12.81 & 10.20 & 12.47 \\
$\mathrm{pH}_{\mathrm{e}}$ & 7.55 & 7.56 & 7.61 & 7.57 \\
$\mathrm{EC}_{\mathrm{e}^{\prime}} \mathrm{dS} \mathrm{m}^{-1}$ & 0.60 & 0.50 & 0.70 & 0.60 \\
$\mathrm{CaCO}_{3^{\prime}} \%$ & 28.70 & 28.70 & 29.60 & 29.00 \\
$\mathrm{OM}_{\text {\% }} \%$ & 1.35 & 1.32 & 1.08 & 1.25 \\
$\mathrm{KDK}_{\text {, meq 100 g }}^{-1}$ & 50.70 & 32.50 & 56.10 & 46.43 \\
\hline
\end{tabular}
$\mathrm{pH}_{\mathrm{e}}$ :Saturasyon ekstraktında toprak reaksiyonu, EC:Saturasyon ekstraktında elektriksel iletkenlik CaCO3:Kireç, OM:Organik madde, KDK:Katyon değișim kapasitesi

$30 \mathrm{~cm}$ derinliklerinde 32.5 ile $56.1 \mathrm{meq} 100 \mathrm{~g}^{-1}$ arasında değișmekte olup ortalama 46.3 meq 100 $\mathrm{g}^{-1}$ olan toprakların KDK içeriği yüksektir. Katyon değișimi toprağın yüzeyinde besin elementlerini tutabilme yeteneğidir. Bu açıdan bakıldığında tuz içeren topraklarda KDKNa+‘un toprak kolloidlerinde tutulması açısından önemli bir parametredir. Çalıșma alanı topraklarının \% $\mathrm{CaCO}_{3}$ içeriği \%28.7 ile \%29.7 arasında değișmekte olup ortalama \%26.0 değerine sahip olan topraklar kireçli sınıfına girmektedir (Çizelge 2). Çalıșma alanı topraklarında yapılan analiz sonuçlarına ilișkin bulgular Çizelge 3'den yararlanılarak değerlendirilmiștir.

Sulama suyunun bazı özelliklerine ilișkin bulgular Çizelge 4 te verilmiștir. Çalıșma alanındaki kullanılan sulama suyu pH değerleri 8.40 olup

Çizelge 3. Toprakların bazı fiziksel ve kimyasal özellikleri ile besin elementi içeriklerini yorumlamaya ilișkin sınır değerleri Table 3. The limit rates for interpretation of the nutrient contents with the some physical and chemical properties of soils

\begin{tabular}{|c|c|c|c|c|c|c|}
\hline $\begin{array}{l}\text { Parametre } \\
\text { Kaynak }\end{array}$ & & & & & & Yeterlik sınıfı \\
\hline \multirow[t]{2}{*}{$\mathrm{CaCO}_{3}, \mathrm{~g} \mathrm{~kg}^{-1}$} & $\begin{array}{l}\text { Çok az } \\
\text { kireçli }\end{array}$ & $\begin{array}{c}\mathrm{Az} \\
\text { kireçli }\end{array}$ & $\begin{array}{l}\text { Orta } \\
\text { kireçli }\end{array}$ & $\begin{array}{l}\text { Fazla } \\
\text { Kireçli }\end{array}$ & $\begin{array}{l}\text { Çok fazla } \\
\text { kireçli }\end{array}$ & \multirow[t]{2}{*}{ Ülgen ve Yurtsever, 1974} \\
\hline & $<10$ & $10-50$ & $50-150$ & $150-250$ & $250<$ & \\
\hline \multirow{2}{*}{$\begin{array}{l}\text { Organik madde, } \\
\mathrm{g} \mathrm{kg}^{-1}\end{array}$} & Çok & $A z$ & Orta & İyi & Yüksek & \multirow{2}{*}{ Ülgen ve Yurtsever, 1974} \\
\hline & $<10$ & $10-20$ & $20-30$ & $30-40$ & $>40$ & \\
\hline \multirow{2}{*}{$\mathrm{EC} d S \mathrm{~m}^{-1}$} & Tuzsuz & Hafif tuzlu & Orta tuzlu & Tuzlu & & \multirow{2}{*}{ Maas, 1986} \\
\hline & $0-4$ & 4-8 & $8-15$ & $>15$ & & \\
\hline \multirow{2}{*}{$\mathrm{pH}$} & Orta asit & Hafif asit & Nötr & Hafif alkali & Kuvvetli alkali & \multirow{2}{*}{ Richards, 1954} \\
\hline & $4.5-5.5$ & $5.5-6.5$ & $6.5-7.5$ & $7.5-8.5$ & $8,5<$ & \\
\hline \multirow{2}{*}{ KDK meq L-1 } & Çok düșük & Düșük & Orta & Yüksek & Çok yüksek & \multirow{2}{*}{ Hazelton ve Murphy, 2016} \\
\hline & $<6.0$ & $6.0-12.0$ & $12.0-25.0$ & $25-40$ & $40<$ & \\
\hline
\end{tabular}


Çizelge 4. Çalıșmada kullanılan sulama suyuna ait bazı özellikler

Table 4. Some features of irrigation water used in the study

\begin{tabular}{|c|c|c|c|c|c|c|c|c|c|c|}
\hline \multirow{2}{*}{$\mathrm{pH}_{\mathrm{w}}$} & \multirow{2}{*}{$\begin{array}{l}\text { EC w } \\
\text { dS } m^{-1}\end{array}$} & \multicolumn{4}{|c|}{ Katyonlar (meq L L-1) } & \multicolumn{3}{|c|}{ Anyonlar (meq L ${ }^{-1}$ ) } & \multirow[t]{2}{*}{ SAR } & \multirow[t]{2}{*}{ ESP \% } \\
\hline & & $\mathrm{Na}^{+}$ & $\mathrm{Ca}^{+2}$ & $\mathrm{Mg}^{+2}$ & $\mathrm{~K}^{+}$ & $\mathrm{Cl}^{-}$ & $\mathrm{HCO}^{3-}$ & $\mathrm{SO}^{-2}$ & & \\
\hline 8.40 & 0.54 & 1.43 & 2.2 & 2.35 & 0.12 & 1.92 & 0.7 & 1.75 & 0.19 & 0.98 \\
\hline
\end{tabular}

Çizelge 5. Sulama suyu kriterlerinin sınıflaması.

Table 5. Classification of irrigation water criteria.

\begin{tabular}{|c|c|c|c|}
\hline Parametre & Değer & Yeterlik sınıfı & Kaynak \\
\hline $\mathrm{pH}$ & $6.5-8.4$ & Uygun & Ayers ve Westcot, 1985 \\
\hline \multirow{5}{*}{$\mathrm{EC}, \mathrm{dS} \mathrm{m}^{-1}$} & $0.10-0.25$ & Mükemmel & \multirow{5}{*}{ Richards, 1954} \\
\hline & $0.25-0.75$ & İyi & \\
\hline & $0.75-2.25$ & İzin verilebilir & \\
\hline & $2.25-5.00$ & Șüpheli & \\
\hline & $>5.00$ & Uygun değil & \\
\hline \multirow{4}{*}{ SAR, meq $L^{-1}$} & $<10$ & Mükemmel & \multirow{4}{*}{ Richards, 1954} \\
\hline & $10-18$ & İyi & \\
\hline & $18-26$ & Șüpheli & \\
\hline & $>26$ & Uygun değil & \\
\hline \multirow{5}{*}{ ESP, \% } & $0-20$ & Mükemmel & \multirow{5}{*}{ Richards, 1954} \\
\hline & $20-40$ & İyi & \\
\hline & $40-60$ & İzin verilebilir & \\
\hline & $60-80$ & Șüpheli & \\
\hline & $>80$ & Uygun değil & \\
\hline
\end{tabular}

sulama için uygun sulardır. Sulama suyu kalitesini belirleyen parametrelerden biri olan EC, suyun elektriği iletme derecesinin bir ölçüsüdür. EC değeri $0.545 \mathrm{dS} \mathrm{m}^{-1}$ olup mükemmel sınıfına girmektedir. Sulama suyunun SAR değeri 0.98 meq $L^{-1}$, ESP değeri ise 0.19 olup mükemmel sınıfına girmektedir
(Çizelge 4). Çalıșma alanında kullanılan sulama suyu analiz sonuçlarına ilișkin bulgular Çizelge 5'den yararlanılarak değerlendirilmiștir.

Varyans analiz sonuçları Çizelge 6' de verilmiștir. Birinci dönemde doz ve tuz çeșidinin $\mathrm{pH}_{\mathrm{e}}$ üzerinde, derinlik ve tuz çeșidinin ise $\mathrm{EC}_{\mathrm{e}}$

Çizelge 6. Çoklu karșılaștırma testi sonucunda izlenen toprak özelliklerine ilișkin P değerleri

Table 6. Coklu karșılaștırma testi sonucunda izlenen toprak özelliklerine ilișkin P değerleri

\begin{tabular}{|c|c|c|c|c|c|c|}
\hline \multirow{2}{*}{ Dönem } & Doz & \multicolumn{3}{|c|}{ Derinlik } & \multicolumn{2}{|l|}{ Tuz çeșidi } \\
\hline & Değișken & $\mathrm{P}$ & Değișken & $\mathrm{P}$ & Değișken & $P$ \\
\hline \multirow{2}{*}{1} & $\mathrm{pH}_{\mathrm{e}}$ & $0.00 *$ & $\mathrm{pH}_{\mathrm{e}}$ & 0.15 & $\mathrm{pHe}$ & $0.00 *$ \\
\hline & $\mathrm{EC}_{\mathrm{e}^{\prime}} \mathrm{dS} \mathrm{m}^{-1}$ & 0.07 & $\mathrm{EC}_{\mathrm{e}^{\prime}} \mathrm{dS} \mathrm{m}^{-1}$ & $0.00 *$ & $\mathrm{EC}_{\mathrm{e}^{\prime}} \mathrm{dS} \mathrm{m}^{-1}$ & $0.04^{*}$ \\
\hline \multirow{2}{*}{2} & $\mathrm{pH}_{\mathrm{e}}$ & 0.69 & $\mathrm{pH}_{\mathrm{e}}$ & 0.36 & $\mathrm{pHe}$ & $0.00 *$ \\
\hline & $\mathrm{EC}_{\mathrm{e}^{\prime}} \mathrm{dS} \mathrm{m}^{-1}$ & 0.33 & $\mathrm{EC}_{\mathrm{e}^{\prime}} \mathrm{dS} \mathrm{m}^{-1}$ & 0.16 & $\mathrm{EC}_{\mathrm{e}^{\prime}} \mathrm{dS} \mathrm{m}^{-1}$ & $0.00 *$ \\
\hline \multirow{2}{*}{3} & $\mathrm{pH}_{\mathrm{e}}$ & 1.00 & $\mathrm{pH}_{\mathrm{e}}$ & $0.02 *$ & $\mathrm{pHe}$ & 0.38 \\
\hline & $\mathrm{EC}_{\mathrm{e}^{\prime}} \mathrm{dS} \mathrm{m}^{-1}$ & 0.13 & $\mathrm{EC}_{\mathrm{e}^{\prime}} \mathrm{dS} \mathrm{m}^{-1}$ & 0.74 & $\mathrm{EC}_{\mathrm{e}^{\prime}} \mathrm{dS} \mathrm{m}^{-1}$ & 0.09 \\
\hline \multirow{2}{*}{4} & $\mathrm{pH}_{\mathrm{e}}$ & $0.05^{*}$ & $\mathrm{pH}_{\mathrm{e}}$ & 0.28 & $\mathrm{pHe}$ & $0.00 *$ \\
\hline & $E C_{e^{\prime}} d S m^{-1}$ & 0.91 & $\mathrm{EC}_{\mathrm{e}^{\prime}} \mathrm{dS} \mathrm{m}^{-1}$ & $0.00^{*}$ & $E C_{e^{\prime}} \mathrm{dS} \mathrm{m}^{-1}$ & 0.31 \\
\hline
\end{tabular}

${ }^{*} p<0,05$ düzeyinde önemlidir 
üzerinde istatistiksel olarak önemli olduğu bulunmuștur. İkinci dönemde ise tuz çeșidinin $\mathrm{pH}_{\mathrm{e}}$ ve $\mathrm{EC}_{\mathrm{e}}$ üzerindeki etkisi istatistiksel olarak önemli olurken, 3.dönemde ise derinliğin $\mathrm{pH}_{\mathrm{e}}$ üzerinde etkisi olduğu belirlenmiștir. Dördüncü dönemde ise doz ve tuz çeșidinin $\mathrm{pH}_{\mathrm{e}^{\prime}}$ derinliğin ise $\mathrm{EC}_{\mathrm{e}}$ üzerindeki etkisi istatistiksel olarak önemli bulunmuștur (Çizelge 6).

Varyans analizi sonrasında ortalamaya etki eden faktörler için yapılan TUKEY testi sonuçları Çizelge 7, 8 ve 9 da verilmiștir. Birinci dönemde pHe için SAR 40 dozu, 1,2 ve 4. dönemde EC için kontrol dozu istatistiksel olarak önemli bulunmuștur.
Üçüncü dönemde $\mathrm{pH}_{\mathrm{e}}$ için tüm dozlar önemli bir farklılık olușturmuștur (Çizelge 7).

Üçüncü dönem hariç toprak örneklemesinin yapıldığı diğer üç dönemde $\mathrm{pH}_{\mathrm{e}}$ için $\mathrm{NaHCO}_{3}$ tuzu, $\mathrm{EC}_{\mathrm{e}}$ için ise $\mathrm{NaCl}$ tuzu önemli farklılık olușturmuștur (Çizelge 8). Dördüncü dönemde $\mathrm{EC}_{\mathrm{e}}$ için $0-10 \mathrm{~cm}$ derinlik önemli bulunmuștur (Çizelge 9).

Çalıșmada $\mathrm{NaCl}$ tuz uygulamalarının her iki

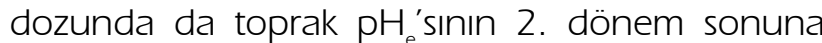
kadar önemli olarak artmadığı, hatta 2. dönem süresince sadece SAR 20 uygulamasında önemli olarak azaldığı ve sulama öncesi döneme benzer sonuçların olduğu, sadece kıș yağıșlarından sonra

Çizelge 7. İzlenen toprak özelliklerinde sulama suyu dozlarına göre yapılan Tukey testi sonuçları

Table 7. Tukey test results based on irrigation water doses in monitored soil properties

\begin{tabular}{cccccccc}
\hline Dönem & Değișken & Kontrol & sig & SAR 20 & sig & SAR 40 & sig \\
\hline \multirow{2}{*}{1} & $\mathrm{PH}_{\mathrm{e}}$ & $7.41 \mathrm{a}$ & 0.73 & $7.35 \mathrm{a}$ & 0.73 & $7.62 \mathrm{~b}$ & 1.00 \\
& $\mathrm{EC}_{\mathrm{e}^{\prime}} \mathrm{dS} \mathrm{m}^{-1}$ & $0.57 \mathrm{a}$ & 1.00 & $1.91 \mathrm{~b}$ & 0.25 & $1.63 \mathrm{~b}$ & 0.25 \\
\multirow{2}{*}{2} & $\mathrm{PH}_{\mathrm{e}}$ & $7.25 \mathrm{a}$ & 0.77 & $7.31 \mathrm{a}$ & 0.77 & $7.28 \mathrm{a}$ & 0.77 \\
& $\mathrm{EC}_{\mathrm{e}^{\prime}} \mathrm{dS} \mathrm{m}^{-1}$ & $0.55 \mathrm{a}$ & 1.00 & $1.85 \mathrm{~b}$ & 0.67 & $2.13 \mathrm{~b}$ & 0.67 \\
\multirow{2}{*}{3} & $\mathrm{PH}_{\mathrm{e}}$ & $7.91 \mathrm{a}$ & 1.00 & $8.13 \mathrm{~b}$ & 1.00 & $8.13 \mathrm{~b}$ & 1.00 \\
& $\mathrm{EC}_{\mathrm{e}^{\prime}} \mathrm{dS} \mathrm{m}^{-1}$ & $0.63 \mathrm{a}$ & 0.06 & $1.06 \mathrm{~b}$ & 0.38 & $0.91 \mathrm{ab}$ & 0.06 \\
\multirow{2}{*}{4} & $\mathrm{PH}_{\mathrm{e}}$ & $7.85 \mathrm{a}$ & 0.68 & $7.88 \mathrm{~b}$ & 0.19 & $7.96 \mathrm{~b}$ & 0.19 \\
& $\mathrm{EC}_{\mathrm{e}^{\prime}} \mathrm{dS} \mathrm{m}^{-1}$ & $0.76 \mathrm{a}$ & 1.00 & $2.01 \mathrm{~b}$ & 0.99 & $2.04 \mathrm{~b}$ & 0.99 \\
\hline
\end{tabular}

Aynı harfler ortak grubu göstermektedir. Aynı satırda aynı harf ile etiketlenen ortalamalar arasında 0.05 düzeyinde fark yoktur.

Çizelge 8. İzlenen toprak özelliklerinde sulama suyu tuz çeșidine göre yapılan Tukey testi sonuçları

Table 8. Tukey test results based on irrigation water salt type in monitored soil properties

\begin{tabular}{|c|c|c|c|c|c|c|c|}
\hline Dönem & Değișken & Kontrol & sig & $\mathrm{NaCl}$ & sig & $\mathrm{NaHCO}_{3}$ & sig \\
\hline \multirow{2}{*}{1} & & $7.41 a$ & 0.95 & $7.59 \mathrm{~b}$ & 1.00 & $7.38 a$ & 0.95 \\
\hline & $\mathrm{EC}, \mathrm{dS} \mathrm{m}^{-1}$ & $0.57 a$ & 0.07 & $0.97 a$ & 0.07 & $2.58 \mathrm{~b}$ & 1.00 \\
\hline \multirow{2}{*}{2} & $\mathrm{pH}_{\mathrm{e}}$ & 7.25a & 0.29 & $7.46 \mathrm{~b}$ & 1.00 & 7.13a & 0.29 \\
\hline & $E C_{,}, \mathrm{dS} \mathrm{m}^{-1}$ & $0.82 a$ & 0.7 & $0.55 a$ & 0.7 & $3.16 b$ & 1.00 \\
\hline \multirow{2}{*}{3} & pHe & 7.91a & 1.00 & $8.11 \mathrm{~b}$ & 0.73 & $8.16 \mathrm{~b}$ & 0.73 \\
\hline & $\mathrm{EC}_{e^{\prime}} \mathrm{dS} \mathrm{m}^{-1}$ & $0.90 a b$ & 0.71 & $1.07 \mathrm{~b}$ & 0.29 & $0.63 a$ & 0.71 \\
\hline \multirow{2}{*}{4} & $\mathrm{pH}_{\mathrm{e}}$ & 7.75a & 0.09 & $7.85 a$ & 0.09 & $7.96 \mathrm{~b}$ & 1.00 \\
\hline & $E C, d S m^{-1}$ & $0.76 a$ & 0.53 & $2.94 \mathrm{~b}$ & 1.00 & $1.11 \mathrm{a}$ & 0.53 \\
\hline
\end{tabular}

Aynı harfler ortak grubu göstermektedir. Aynı satırda aynı harf ile etiketlenen ortalamalar arasında 0.05 düzeyinde fark yoktur.

Çizelge 9. İzlenen toprak özelliklerinde toprak derinliğine göre yapılan Tukey testi sonuçları

Table 9. Tukey test results based on irrigation soil depth in monitored soil properties

\begin{tabular}{cccccccc}
\hline Dönem & Değișken & $0-10 \mathrm{~cm}$ & sig & $10-20 \mathrm{~cm}$ & sig & $20-30 \mathrm{~cm}$ & sig \\
\hline \multirow{2}{*}{1} & $\mathrm{pH}_{\mathrm{e}}$ & $7.56 \mathrm{a}$ & 0.6 & $7.49 \mathrm{ab}$ & 0.21 & $7.37 \mathrm{~b}$ & 0.21 \\
& $\mathrm{EC}_{e^{\prime}} \mathrm{dS} \mathrm{m}^{-1}$ & $1.27 \mathrm{a}$ & 0.05 & $1.66 \mathrm{ab}$ & 0.05 & $1.67 \mathrm{a}$ & 0.05 \\
\hline \multirow{2}{*}{2} & $\mathrm{pH}_{\mathrm{e}}$ & $7.36 \mathrm{a}$ & 0.23 & $7.23 \mathrm{a}$ & 0.23 & $7.27 \mathrm{a}$ & 0.23 \\
& $\mathrm{EC}_{e^{\prime}} \mathrm{dS} \mathrm{m}^{-1}$ & $1.27 \mathrm{a}$ & 0.05 & $1.66 \mathrm{ab}$ & 0.05 & $1.50 \mathrm{a}$ & 0.13 \\
\hline \multirow{2}{*}{3} & $\mathrm{pH}_{\mathrm{e}}$ & $8.18 \mathrm{a}$ & 0.12 & $8.07 \mathrm{a}$ & 0.12 & $8.02 \mathrm{~b}$ & 0.6 \\
& $\mathrm{EC}_{e^{\prime}} \mathrm{dS} \mathrm{m}^{-1}$ & $0.89 \mathrm{a}$ & 0.71 & $0.88 \mathrm{a}$ & 0.71 & $0.97 \mathrm{a}$ & 0.71 \\
\hline \multirow{2}{*}{4} & $\mathrm{pH}_{\mathrm{fe}}$ & $7.86 \mathrm{a}$ & 0.59 & $7.92 \mathrm{a}$ & 0.59 & $7.94 \mathrm{a}$ & 0.59 \\
& $\mathrm{EC}_{e^{\prime}} \mathrm{dS} \mathrm{m}^{-1}$ & $2.28 \mathrm{a}$ & 1.00 & $1.26 \mathrm{~b}$ & 0.92 & $1.38 \mathrm{~b}$ & 0.92 \\
\hline
\end{tabular}


Çizelge 10. SAR $20 \mathrm{NaCl}$ uygulamasında pHe ortalamalarına ait Tukey çoklu gruplandırması

Table 10. Tukey multiple grouping of $p H e$ averages in SAR $20 \mathrm{NaCl}$ application

\begin{tabular}{cccc}
\hline Toprak derinliği & $0-10 \mathrm{~cm}$ & $10-20 \mathrm{~cm}$ & $20-30 \mathrm{~cm}$ \\
\hline Dönem & $\mathrm{A} . \mathrm{O} \pm \mathrm{SH}$ & $\mathrm{A} . \mathrm{O} \pm \mathrm{SH}$ & $\mathrm{A} . \mathrm{O} \pm \mathrm{SH}$ \\
\hline Bașlangıc & $7.55 \mathrm{ab} \pm 0.38$ & $7.53 \mathrm{ab} \pm 0.13$ & $7.61 \mathrm{ab} \pm 0.13$ \\
1 & $7.50 \mathrm{ab} \pm 0.27$ & $7.23 \mathrm{a} \pm 0.14$ & $7.15 \mathrm{a} \pm 0.15$ \\
2 & $7.16 \mathrm{a} \pm 0.44$ & $7.06 \mathrm{a} \pm 0.12$ & $7.27 \mathrm{ab} \pm 0.08$ \\
3 & $8.20 \mathrm{~b} \pm 0.11$ & $8.10 \mathrm{c} \pm 0.08$ & $8.11 \mathrm{c} \pm 0.02$ \\
4 & $7.73 \mathrm{ab} \pm 0.20$ & $7.79 \mathrm{bc} \pm 0.07$ & $7.66 \mathrm{bc} \pm 0.07$ \\
\hline
\end{tabular}

Aynı harfler ortak grubu göstermektedir. Aynı sütunda aynı harf ile etiketlenen ortalamalar arasında 0.05 düzeyinde fark yoktur. AO: Aritmetik ortalama SH: Standart hata

3. dönemden itibaren $\mathrm{pH}_{\mathrm{e}}$ 'nın artmaya bașladığı görülmektedir. Bașlangıç $\mathrm{pH}_{\mathrm{e}}$ sı 7.55 iken $\mathrm{NaCl}$ sulama konularında 3. ve 4. dönemde pHe 8.0 i așmıștır (Șekil 1). Çalıșmamızda NaCl tuz çeșidinin $\mathrm{pH}_{\mathrm{e}}$ üzerine istatistiksel olarak etkisinin olmadığı belirlenmiștir (Çizelge 8). NaCl tuz uygulamalarında

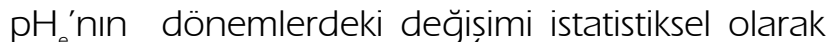
Çizelge 10 ve 11 de verilmiștir. Bu durum toprakların tamponlama özelliklerinden dolayı, $\mathrm{Na}+$ un etkisini geç göstermesi ve ortamdaki $\mathrm{Na}^{+}$ iyonunun $\mathrm{Ca}^{+2}$ iyonlarını yıkaması ile açıklanabilir. Tan (1993), yaptığı çalıșmasında toprakta sodyum

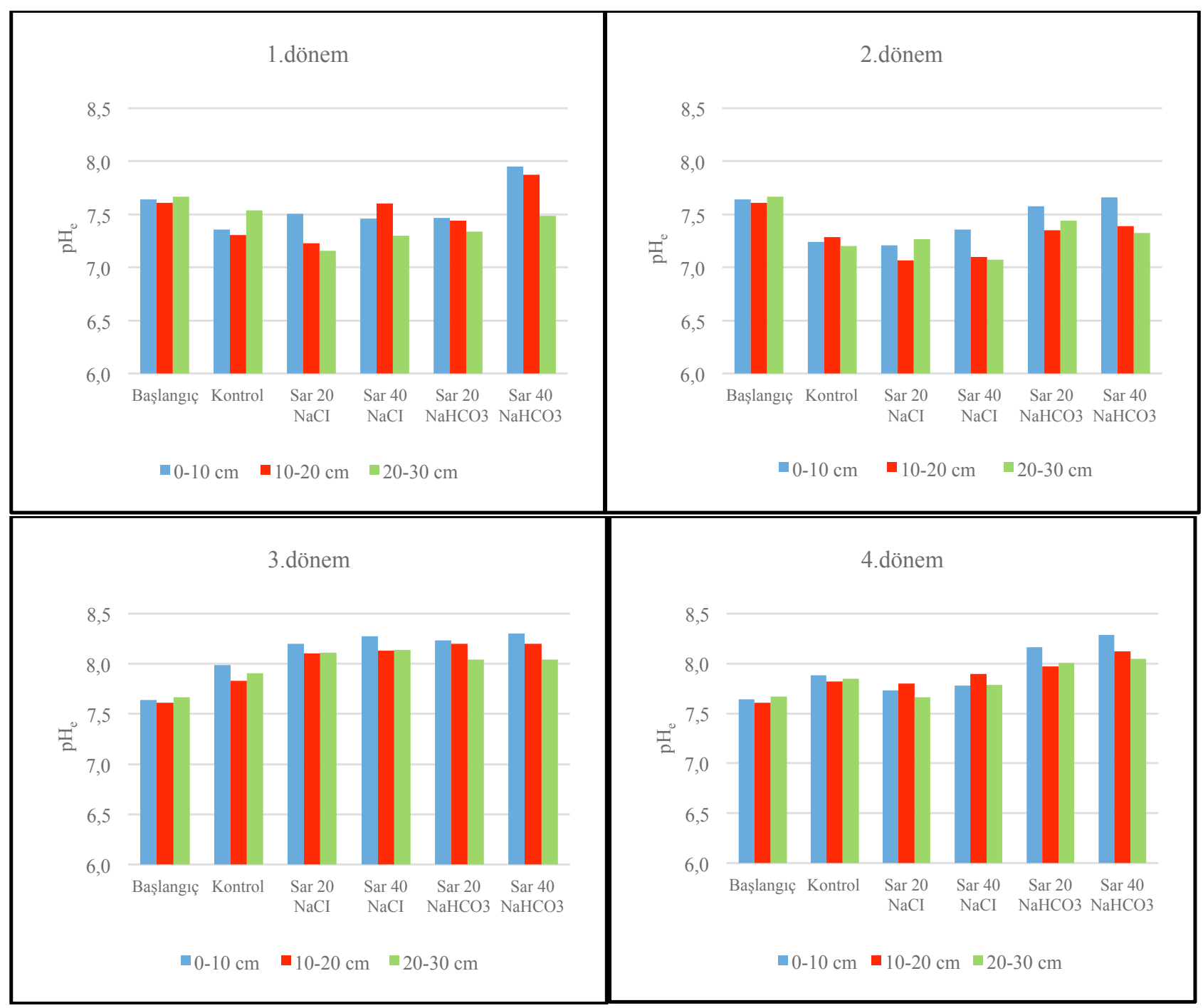

Șekil 1. Toprak örneklemesi yapılan dönemlere göre $\mathrm{pH}_{\mathrm{e}}$ değișimi

Figure 1. $\mathrm{pH}_{e}$ change according to soil sampling periods 
Çizelge 11. SAR $40 \mathrm{NaCl}$ uygulamasında $\mathrm{pH}_{\mathrm{e}}$ ortalamalarına ait Tukey çoklu gruplandırması

Table 11. Tukey multiple grouping of $\mathrm{pH}_{\mathrm{e}}$ averages in SAR $40 \mathrm{NaCl}$ application

\begin{tabular}{cccc}
\hline Toprak derinliği & $0-10 \mathrm{~cm}$ & $10-20 \mathrm{~cm}$ & $20-30 \mathrm{~cm}$ \\
\hline Dönem & $\mathrm{A} . \mathrm{O} \pm \mathrm{SH}$ & $\mathrm{A} . \mathrm{O} \pm \mathrm{SH}$ & $\mathrm{A} . \mathrm{O} \pm \mathrm{SH}$ \\
\hline Bașlangıç & $7.55 \mathrm{a} \pm 0.22$ & $7.53 \mathrm{ab} \pm 0.13$ & $7.61 \mathrm{ab} \pm 0.13$ \\
1 & $7.46 \mathrm{a} \pm 0.10$ & $7.60 \mathrm{~b} \pm 0.03$ & $7.30 \mathrm{ab} \pm 0.12$ \\
2 & $7.12 \mathrm{a} \pm 0.09$ & $7.05 \mathrm{a} \pm 0.10$ & $7.07 \mathrm{a} \pm 0.10$ \\
3 & $8.27 \mathrm{ab} \pm 0.14$ & $8.13 \mathrm{c} \pm 0.13$ & $8.13 \mathrm{c} \pm 0.06$ \\
4 & $7.65 \mathrm{~b} \pm 0.27$ & $7.89 \mathrm{bc} \pm 0.03$ & $7.78 \mathrm{bc} \pm 0.06$ \\
\hline
\end{tabular}

Aynı harfler ortak grubu göstermektedir. Aynı sütunda aynı harf ile etiketlenen ortalamalar arasında 0.05 düzeyinde fark yoktur. AO: Aritmetik ortalama SH: Standart hata

konsantrasyonun artmasının toprak pH'sını etkilemediğini ve bunun nedeninin toprakların tamponlama özelliğinin olduğunu belirtmiștir. Sreenıvas (2008), yaptığı çalıșmasında saturasyon ekstraktının tuzluluğu ile toprak pH'sı arasında negatif bir ilișkinin olduğunu, sulama suyundaki $\mathrm{NaCl}$ tuz konsantrasyonunun yüksek olmasının toprak $\mathrm{pH}$ 'sını yükseltmediğini tespit etmiștir. Pessoa vd. (2019), kumlu ve siltli tın bünyeye sahip topraklarda farklı tuz seviyeleri ve farklı tuz çeșitleri hazırlanan sular ile yaptıkları çalıșmalarında sulamalar sonrasında $\mathrm{Cl}^{-}$içeren tuzların kullanılması ile sulama suyu tuzluluğunun arttığını, kumlu topraklarda ortamda suda çözünebilir $\mathrm{Cl}$ konsantrasyonunun $\mathrm{CO}_{3}^{-2}$ ve $\mathrm{HCO}_{3}^{-}$iyonlarına göre yüksek konsantrasyonda olması ile toprak ekstraktında pH yı düșürdüğünü ifade etmișlerdir.

$\mathrm{NaHCO}_{3}$ tuz uygulamalarının pHe'ları 1 ve 2 dönem sonuna kadar değișmemiș, 3. dönemle birlikte her iki dozda özellikle SAR 40 dozunda artma olmuștur. SAR 40 dozunda artıș 1. dönemden itibaren bașlamıș ve 4.dönemde $\mathrm{pH}_{\mathrm{e}}$ 8.28'e ulașmıștır (Șekil 1) Sulama sularının tuz çeșidi SAR dozlarına göre $\mathrm{pH}_{\mathrm{e}}$ değișiminin özellikle $\mathrm{NaHCO}_{3}$ tuz uygulamalarında 3.ve 4.dönemden sonra daha belirgin olduğu görülmüștür (Șekil 1) (Çizelge 12 ve 13). SAR $40 \mathrm{NaHCO}_{3}$ uygulamasında ise 3. ve 4. dönem $\mathrm{pH}_{\mathrm{e}}$ ortalamaları diğer dönemlere göre istatistiksel olarak önemli bulunmuștur /Çizelge

Çizelge 12. SAR $20 \mathrm{NaHCO}_{3}$ uygulamasında $\mathrm{pH}_{\mathrm{e}}$ ortalamalarına ait Tukey çoklu gruplandırması

Table 12. Tukey multiple grouping of $\mathrm{pH}_{e}$ averages in $\mathrm{SAR} 2 \mathrm{O} \mathrm{NaHCO}$ application

\begin{tabular}{cccc}
\hline Toprak derinliği & $0-10 \mathrm{~cm}$ & $10-20 \mathrm{~cm}$ & $20-30 \mathrm{~cm}$ \\
\hline Dönem & $\mathrm{A} . \mathrm{O} \pm \mathrm{SH}$ & $\mathrm{A} . \mathrm{O} \pm \mathrm{SH}$ & $\mathrm{A} . \mathrm{O} \pm \mathrm{SH}$ \\
\hline Bașlangıç & $7.55 \mathrm{a} \pm 0.2$ & $7.53 \mathrm{a} \pm 0.13$ & $7.61 \mathrm{ab} \pm 0.13$ \\
1 & $7.47 \mathrm{a} \pm 0.11$ & $7.44 \mathrm{a} \pm 0.06$ & $7.33 \mathrm{a} \pm 0.05$ \\
2 & $7.57 \mathrm{ab} \pm 0.09$ & $7.35 \mathrm{a} \pm 0.03$ & $7.44 \mathrm{~s} \pm 0.11$ \\
3 & $8.23 \mathrm{c} \pm 0.07$ & $8.12 \mathrm{~b} \pm 0.04$ & $8.0 \mathrm{~b} \pm 0.14$ \\
4 & $8.16 \mathrm{bc} \pm 0.06$ & $7.97 \mathrm{~b} \pm 0.08$ & $8.00 \mathrm{~b} \pm 0.04$
\end{tabular}

Aynı harfler ortak grubu göstermektedir. Aynı sütunda aynı harf ile etiketlenen ortalamalar arasında 0.05 düzeyinde fark yoktur. AO: Aritmetik ortalama SH: Standart hata

Çizelge 13. SAR $20 \mathrm{NaHCO}_{3}$ uygulamasında $\mathrm{pH}_{\mathrm{e}}$ ortalamalarına ait Tukey çoklu gruplandırması

Table 13. Tukey multiple grouping of $\mathrm{pH}_{\mathrm{e}}$ averages in SAR $40 \mathrm{NaHCO}_{3}$ application

\begin{tabular}{cccc}
\hline Toprak derinliği & $0-10 \mathrm{~cm}$ & $10-20 \mathrm{~cm}$ & $20-30 \mathrm{~cm}$ \\
\hline Dönem & $\mathrm{A} . \mathrm{O} \pm \mathrm{SH}$ & $\mathrm{A} . \mathrm{O} \pm \mathrm{SH}$ & $\mathrm{A} . \mathrm{O} \pm \mathrm{SH}$ \\
\hline Bașlangıç & $7.55 \mathrm{a} \pm 0.22$ & $7.53 \mathrm{ab} \pm 0.13$ & $7.61 \mathrm{ab} \pm 0.13$ \\
1 & $7.97 \mathrm{ab} \pm 0.07$ & $7.87 \mathrm{bc} \pm 0.05$ & $7.69 \mathrm{a} \pm 0.02$ \\
2 & $7.60 \mathrm{ab} \pm 0.16$ & $7.39 \mathrm{a} \pm 0.06$ & $7.32 \mathrm{a} \pm 0.10$ \\
3 & $8.23 \mathrm{~b} \pm 0.01$ & $8.15 \mathrm{c} \pm 0.05$ & $7.89 \mathrm{bc} \pm 0.01$ \\
4 & $8.28 \mathrm{~b} \pm 0.11$ & $8.12 \mathrm{c} \pm 0.02$ & $8.05 \mathrm{c} \pm 0.06$ \\
\hline
\end{tabular}

Aynı harfler ortak grubu göstermektedir. Aynı sütunda aynı harf ile etiketlenen ortalamalar arasında 0.05 düzeyinde fark yoktur. AO: Aritmetik ortalama SH: Standart hata 
13). Üçüncü dönemde özellikle $\mathrm{NaHCO}_{3}$ sulama uygulamalarında $\mathrm{pH}_{\mathrm{e}}$ 'nın artmasının nedeni ise kıș yağıșları ile çözünebilir tuzlar toprak profilinden așağıya doğru yıkandıktan sonra değișebilir haldeki $\mathrm{Na}^{+}$un hidrolize olarak $\mathrm{NaOH}$ (sodyum hidroksit) olușturması, olușan $\mathrm{NaOH}$ un havadan absorbe edilen veya mikroorganizmalar tarafından üretilen $\mathrm{CO} 2$ (karbondioksit) ile tepkimeye girerek $\mathrm{Na}_{2} \mathrm{CO}_{3}$ (Sodyum karbonat)'lara dönüșmesi ve sulama suyundaki yüksek bikarbonat miktarıdır. Gupta vd. (1984), alkali topraklarda sulama suyundaki $\mathrm{NaHCO}_{3}$ 'ın varlığından dolayı tuzluluğun artmasına bağlı olarak toprak pH sının arttığını bildirmișlerdir. Karbonat ve bikarbonat iyonlarının artması, suyun $\mathrm{pH}$ değerini yükselterek alkali özelliklerin hakim olmasını sağlamaktadır. Bunun sonucu olarak kalsiyum çöker ve sistemde sodyum bașat duruma geçmektedir (Kanber ve Ünlü, 2010). Oian ve Mecham (2005), yaptıkları çalıșmada toprak pH sındaki 0.2 ünitelik artıșın sulama suyundaki yüksek bikarbonattan kaynaklandığın belirtmișlerdir. Yine Costa vd. (2015), yüksek sodyum bikarbonat tuzu içeriğine sahip sulama sularının kullanıldığı çalıșmada sulama yapılan lokasyonlarda sulama öncesi pH 5.42 iken, sulama sonrası pH 6.08 e yükseldiğini ve bu değișimin $p<0,05$ düzeyinde uygulamalar arasında istatistiksel olarak önemli olduğunu tespit etmișlerdir. Pondkule vd. (2019), Hindistan da yaptıkları çalıșmada bir yıl boyunca sulama öncesi ve sulama sonrası alınan toprak örneklerinde bazı toprak özelliklerinin değișimin, ortaya koymușlardır. Çalıșmada sulama öncesi toprak ekstraktında $\mathrm{pH}$ 'sı 8.65 ile 8.94 arasında değișirken sulama sonrasında 8.76 ile 8.96 arasında değișim göstermiștir. Araștırıcılar toprak $\mathrm{pH}^{\prime}$ sındaki bu değișimin toprak suyundaki çözünebilir tuzlardan $\mathrm{HCO}_{3}$ - 'ın baskın olmasından kaynaklandığını ifade etmișlerdir.

Tuzlu sulamalarınyapıldığı 1, 2ve4. dönemlerde, hem toprak yüzeyinde hem de altında ECe değerlerinin özellikle NaCl'lü suyun kullanılmasıyla, her iki tuz çeșidinde de SAR daki artıșa paralel olarak arttığı belirlenmiștir. Ayrıca tuzların $\mathrm{NaCl}$ uygulamalarında $10-20 \mathrm{~cm}$ ve $20-30 \mathrm{~cm}$ derinliğe kadar ulaștığı ve tuz birikimi olduğu tespit edilmiștir (Șekil 2). Bir çözeltideki toplam tuz konsantrasyonu ile çözeltinin elektriksel iletkenliği arasında doğrusal bir ilișki mevcuttur (Richards, 1954; Esechie, 1994). Bundan dolayı $\mathrm{Na}^{+}$içeren sulama suları uygulamaları sonrasında tuz konsantrasyonuna bağlı olarak özellikle NaCl tuz uygulamalarında tuz uygulaması yapılan dönemlerde istatistiksel olarak önemli farklıklar bulunmuștur (Çizelge 14 ve 15). Bu farklılığın nedeni olarak tuz uygulamaları ile

Çizelge 14. SAR $20 \mathrm{NaCl}$ uygulamasında $\mathrm{EC}_{\mathrm{e}}$ ortalamalarına ait Tukey çoklu gruplandırması

Table 14. Tukey multiple grouping of $E C_{e}$ averages in SAR $20 \mathrm{NaCl}$ application

\begin{tabular}{cccc}
\hline Toprak derinliği & $0-10 \mathrm{~cm}$ & $10-20 \mathrm{~cm}$ & $20-30 \mathrm{~cm}$ \\
\hline Dönem & $\mathrm{A} . \mathrm{O} \pm \mathrm{SH}$ & $\mathrm{A} . \mathrm{O} \pm \mathrm{SH}$ & $\mathrm{A} . \mathrm{O} \pm \mathrm{SH}$ \\
\hline Bașlangıc & $0.62 \mathrm{a} \pm 0.01$ & $0.58 \mathrm{a} \pm 0.06$ & $0.66 \mathrm{a} \pm 0.07$ \\
1 & $3.19 \mathrm{~b} \pm 0.12$ & $2.41 \mathrm{~b} \pm 0.34$ & $2.77 \mathrm{c} \pm 0.26$ \\
2 & $4.72 \mathrm{~b} \pm 0.61$ & $2.39 \mathrm{~b} \pm 0.45$ & $2.16 \mathrm{bc} \pm 0.28$ \\
3 & $0.99 \mathrm{a} \pm 0.05$ & $1.15 \mathrm{ab} \pm 0.20$ & $1.32 \mathrm{ab} \pm 0.13$ \\
4 & $3.32 \mathrm{~b} \pm 0.53$ & $2.05 \mathrm{ab} \pm 0.43$ & $2.63 \mathrm{c} \pm 0.40$ \\
\hline
\end{tabular}

Aynı harfler ortak grubu göstermektedir. Aynı sütunda aynı harf ile etiketlenen ortalamalar arasında 0.05 düzeyinde fark yoktur. AO: Aritmetik ortalama SH: Standart hata

Çizelge 15. SAR $40 \mathrm{NaCl}$ uygulamasında $\mathrm{EC}_{\mathrm{e}}$ ortalamalarına ait Tukey çoklu gruplandırması Table 15. Tukey multiple grouping of EC averages in SAR $40 \mathrm{NaCl}$ application

\begin{tabular}{cccc}
\hline Toprak derinliği & $0-10 \mathrm{~cm}$ & $10-20 \mathrm{~cm}$ & $20-30 \mathrm{~cm}$ \\
\hline Dönem & $\mathrm{A} . \mathrm{O} \pm \mathrm{SH}$ & $\mathrm{A} . \mathrm{O} \pm \mathrm{SH}$ & $\mathrm{A} . \mathrm{O} \pm \mathrm{SH}$ \\
\hline Bașlangıç & $0.62 \mathrm{a} \pm 0.01$ & $0.58 \mathrm{a} \pm 0.06$ & $0.66 \mathrm{a} \pm 0.07$ \\
1 & $3.17 \mathrm{bc} \pm 0.20$ & $3.28 \mathrm{bc} \pm 0.36$ & $3.03 \mathrm{~b} \pm 0.31$ \\
2 & $4.65 \mathrm{~cd} \pm 0.86$ & $3.70 \mathrm{c} \pm 0.19$ & $3.10 \mathrm{~b} \pm 0.12$ \\
3 & $1.19 \mathrm{ab} \pm 0.09$ & $0.94 \mathrm{a} \pm 0.15$ & $1.00 \mathrm{a} \pm 0.08$ \\
4 & $5.53 \mathrm{~d} \pm 0.38$ & $2.40 \mathrm{bc} \pm 0.26$ & $2.55 \mathrm{~b} \pm 0.15$ \\
\hline
\end{tabular}

Aynı harfler ortak grubu göstermektedir. Aynı sütunda aynı harf ile etiketlenen ortalamalar arasında 0.05 düzeyinde fark yoktur. AO: Aritmetik ortalama SH: Standart hata 
Çizelge 16. SAR $20 \mathrm{NaHCO}_{3}$ uygulamasında $\mathrm{EC}_{\mathrm{e}}$ ortalamalarına ait Tukey çoklu gruplandırması

Table 16. Tukey multiple grouping of EC, averages in $\mathrm{SAR}_{2} \mathrm{ONaHCO}$ application

\begin{tabular}{cccc}
\hline Toprak derinliği & $0-10 \mathrm{~cm}$ & $10-20 \mathrm{~cm}$ & $20-30 \mathrm{~cm}$ \\
\hline Dönem & $\mathrm{A} . \mathrm{O} \pm \mathrm{SH}$ & $\mathrm{A} . \mathrm{O} \pm \mathrm{SH}$ & $\mathrm{A} . \mathrm{O} \pm \mathrm{SH}$ \\
\hline Bașlangıc & $0.62 \mathrm{a} \pm 0.01$ & $0.58 \mathrm{a} \pm 0.06$ & $0.66 \mathrm{a} \pm 0.07$ \\
1 & $0.73 \mathrm{a} \pm 0.14$ & $1.73 \mathrm{~b} \pm 0.45$ & $0.77 \mathrm{a} \pm 0.04$ \\
2 & $0.97 \mathrm{ab} \pm 0.05$ & $0.67 \mathrm{ab} \pm 0.13$ & $0.65 \mathrm{a} \pm 0.05$ \\
3 & $0.95 \mathrm{ab} \pm 0.10$ & $0.78 \mathrm{ab} \pm 0.04$ & $0.83 \mathrm{a} \pm 0.07$ \\
4 & $1.40 \mathrm{~b} \pm 0.21$ & $1.55 \mathrm{~b} \pm 0.06$ & $0.89 \mathrm{a} \pm 0.18$ \\
\hline
\end{tabular}

Aynı harfler ortak grubu göstermektedir. Aynı sütunda aynı harf ile etiketlenen ortalamalar arasında 0.05 düzeyinde fark yoktur. AO: Aritmetik ortalama SH: Standart hata

Çizelge 17. SAR $40 \mathrm{NaHCO}_{3}$ uygulamasında $\mathrm{EC}_{\mathrm{e}}$ ortalamalarına ait Tukey çoklu gruplandırması

Table 17. Tukey multiple grouping of EC averages in $\mathrm{SAR}_{4} \mathrm{OONaHCO}$ application

\begin{tabular}{cccc}
\hline Toprak derinliği & $0-10 \mathrm{~cm}$ & $10-20 \mathrm{~cm}$ & $20-30 \mathrm{~cm}$ \\
\hline Dönem & $\mathrm{A} . \mathrm{O} \pm \mathrm{SH}$ & $\mathrm{A} . \mathrm{O} \pm \mathrm{SH}$ & $\mathrm{A} . \mathrm{O} \pm \mathrm{SH}$ \\
\hline Bașlangıç & $0.62 \mathrm{a} \pm 0.01$ & $0.58 \mathrm{a} \pm 0.06$ & $0.66 \mathrm{a} \pm 0.07$ \\
1 & $1.37 \mathrm{~b} \pm 0.15$ & $0.68 \mathrm{a} \pm 0.05$ & $0.81 \mathrm{a} \pm 0.04$ \\
2 & $1.20 \mathrm{~b} \pm 0.23$ & $0.86 \mathrm{a} \pm 0.05$ & $0.77 \mathrm{a} \pm 0.07$ \\
3 & $0.89 \mathrm{ab} \pm 0.08$ & $0.82 \mathrm{a} \pm 0.07$ & $0.78 \mathrm{a} \pm 0.17$ \\
4 & $1.38 \mathrm{~b} \pm 0.01$ & $0.85 \mathrm{a} \pm 0.10$ & $0.85 \mathrm{a} \pm 0.06$ \\
\hline
\end{tabular}

Aynı harfler ortak grubu göstermektedir. Aynı sütunda aynı harf ile etiketlenen ortalamalar arasında 0.05 düzeyinde fark yoktur. AO: Aritmetik ortalama SH: Standart hata

toprağa devamlı tuz ilavesinin olması ve $\mathrm{NaCl}$ tuz çeșidinin sudaki çözünürlüğünün yüksek olması ile özellikle yüzeyde $(0-10 \mathrm{~cm})$ ve yüzeyden itibaren alt derinliklerde birikmesi söylenebilir. Meiri ve Plaut (1985), sulamada kullanılan suların etkisiyle belirli miktardaki tuzun bitki kök bölgesine iletildiğini, kıș yağıșlarının yetersiz veya yıkama yapılmadığı takdirde zamanla profilde tuz birikmesi olacağını ve toprak tuzluluğunu etkileyen asıl etmenin sulama ile toprağa verilen tuz miktarının olduğunu belirtmișlerdir. Rana vd. (2010), Hindistan Haryana'da uzun süre tarım arazilerinde kanal suyunun kullanıldığı çalıșmasında toprak EC değerlerinin $0.99 \mathrm{dS} \mathrm{\textrm {m } ^ { - 1 }}$ den $1.65 \mathrm{dS} \mathrm{m}^{-1}$ ye kadar farklılaștığının tespit etmișlerdir. Avcı (2018), lizimetre koșullarında farklı kalitedeki sulama sularının değișik yıkama oranları ile kullanılmasının toprak tuzluluğuna olan etkilerini izlediği çalıșmasında, farklı zamanlarda tuzlu sular kullanmıș ve devam eden sulamalar neticesinde toprak profilinde tuzluluğun zaman içerisinde arttığını ve yapılan yıkamalarla üst topraktaki tuzların sürekli alt toprağa tașındığını ifade etmiștir. Sulama suyuna bağı olarak toprakta tuz birikiminin olacağına dair çalıșmamızla benzer sonuçlar veren çalıșmalar mevcuttur (Mostafazadeh-Fard vd. 2007; Rana vd. 2010; Alsadon vd. 2013; Hasan vd. 2015; Tunç ve Șahin, 2015; Üzen, 2015; Karakoç, 2016; Liu vd. 2016; Abu-Alrub vd. 2018; Bouaroudj vd. 2019) EC üzerine derinliğin etkisi istatistiksel olarak da önemli bulunmuștur (Çizelge 6). Toprak yüzeyinden profilin alt katmanlarına doğru yıkanan tuz ve kirecin biriktiği derinlik, toprağın su tutma kapasitesine, toprak tekstürüne, geçirgenliğe ve toprak içine sızan su miktarına bağlıdır (Amit vd. 2010). Üçüncü dönemde ise biriken tuzların yüzeyden itibaren tüm derinliklerde yıkandığı ve $E C_{e}$ değerlerinin düștüğü görülmektedir (Șekil 2). Çalıșma alanındaki yağıșların büyük kısmı kıș ve ilkbahar mevsimlerinde düșmektedir. Dolayısıyla bu dönemlerde, büyük olasılıkla, profildeki tuz yağıșlarla profilin derinliklerine kadar yıkanmaktadır. Yapılan birçok çalıșmada bir sulama alanında sulama mevsimi boyunca toprakta tuz içeriğinin arttığı, kıș periyodunda yağıșların yıkama etkisinden dolayı tuzluluğun azalabileceği ifade edilmiștir (Yurtseven ve Güngör, 1990; Yurtseven ve Sönmez, 1996; Yurtseven vd. 2012; Alsadon vd. 2013; Wang vd.2015; Liu vd. 2016; AbuAlrub vd. 2018; Tașan, 2018; Pessoa vd.2019).

SAR $20 \mathrm{NaHCO} 3$ uygulamasında 2. ve 4. dönemde ECe değerleri artıș göstermiștir. 1.dönemde 10-20 cm derinlikte, 3. dönemde ise 
10-20 ve 20-30 cm derinlikte ECe' de artıș olduğu görülmektedir SAR $40 \mathrm{NaHCO}_{3}$ uygulamasında bașlangıç dönemine göre 1,2 ve 4.dönemlerde $\mathrm{EC}_{\mathrm{e}}$ değerleri artıș göstermiștir. Bașlangıç döneminde EC $0.60 \mathrm{dS} \mathrm{m}^{-1}$ iken 4.dönemde $0-10 \mathrm{~cm}$ toprak derinliğinde $\mathrm{EC}_{e^{\prime}} \mathrm{NaCl}$ uygulamasının SAR 20 dozunda $3.32 \mathrm{dS} \mathrm{m}^{-1}$, SAR 40 dozunda ise $5.53 \mathrm{dS}$ $\mathrm{m}^{-1}$ e ulașmıștır. Yine 0-10 cm toprak derinliğinde 4.dönemde $\mathrm{EC}_{\mathrm{e}}^{\prime}$ nin $\mathrm{NaHCO}_{3}$ uygulamasında SAR 20 dozunda $1.40 \mathrm{dS} \mathrm{m}^{-1}$, SAR 40 dozunda ise $1.38 \mathrm{dS} \mathrm{m}^{-1}$ olduğu belirlenmiștir (Șekil 2). Fakat $\mathrm{NaHCO}_{3}$ uygulamalarındaki $\mathrm{EC}_{e}$ değerlerindeki bu artıșlar $\mathrm{NaCl}$ uygulamalarındaki kadar belirgin değildir. $\mathrm{NaHCO}_{3}$ uygulamalarında $\mathrm{EC}_{\mathrm{e}}$ ortalamalarının dönemsel olarak değișimi istatistik sonuçları Çizelge 16 ve 17 de verilmiștir. Buna göre $\mathrm{NaHCO}_{3}$ uygulamalarının $\mathrm{EC}_{\mathrm{e}}$ 'nin değișimine etkisi olmadığı belirlenmiștir. $\mathrm{NaHCO}_{3}$ tuz çeșidinin sudaki çözünürlüğünün $\mathrm{NaCl}$ tuz çeșidine göre daha düșük olması bu sonucun çıkmasına neden olmuștur. Ayrıca $\mathrm{NaHCO}_{3}$ sulama konularında tuz çeșidinin çözünürlüğünün az olmasından dolayı tuzlar alt derinliklere ulașamamıștır (Șekil 4.1). NaCl tuzunun $20^{\circ} \mathrm{C}$ de çözünürlüğü $29.4 \mathrm{~g} / 100 \mathrm{~g} \mathrm{H}$ iken, $\mathrm{NaHCO}_{3}$ tuzunun ise $8.4 \mathrm{~g} / 100 \mathrm{~g} \mathrm{H}_{2} \mathrm{O}$ dır (Munsuz vd. 2001).

\section{SONUÇLAR}

Toprak çözelti içerisindeki tuzların konsantrasyonu ve tuz çeșidi, toprakların $\mathrm{pH}$ ve EC gibi özelliklerinde değișimleri etkilemiștir. Çalıșmada
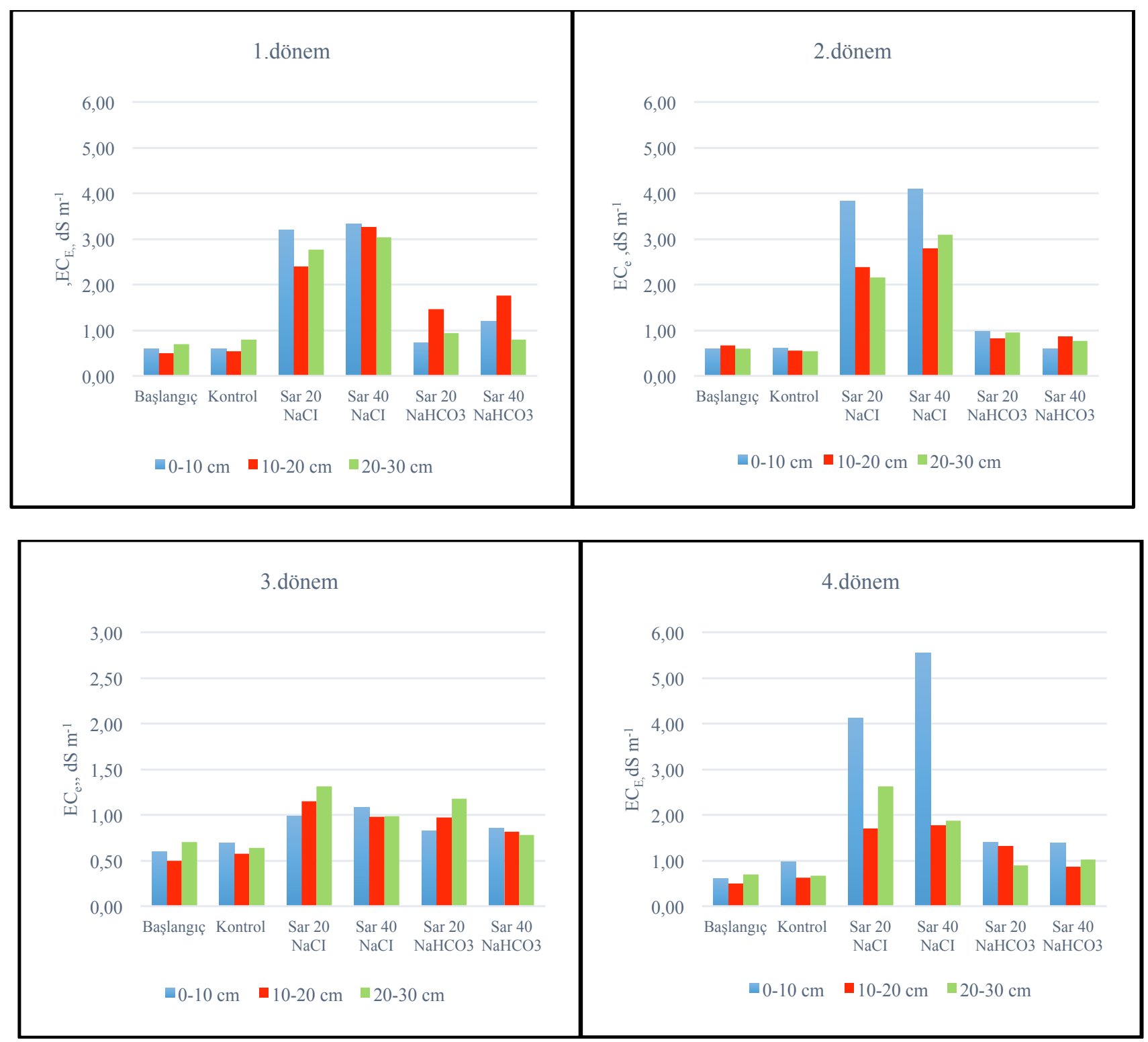

Șekil 2. Toprak örneklemesi yapılan dönemlere göre EC 'nin değișimi

Figure 2. $E C_{e}$ change according to soil sampling periods 
toprakların tamponlama yeteneğinden dolayı, $\mathrm{pH}_{\mathrm{e}}$ nın değișik SAR değerlerine sahip sulama sularının deneme süresince farklı dönemlerde yapılan on beș sulama sonrasında özellikle $\mathrm{NaHCO}_{3}$ sulama uygulamalarında SAR dozunun artmasıyla pHe'nin kıș sonrası dönemde $\mathrm{Na}^{+}$tuzlarının yıkanmasından dolayı önemli düzeyde arttığı belirlenmiștir. Ancak bu değișim toprakların tamponlama özelliklerinden dolayı deneme süresince belirgin olmamıștır. Değișim çözeltisinde bir katyonun konsantrasyonu veya diğer katyonlara nisbi oranı arttıkça, kolloidler tarafından tutulan miktarı da artmaktadır. Toprak yüzeyindeki $E C_{e}$ değerleri ise kıș ve ilkbahar yağıșlarından dolayı 3.dönem hariç, suların SAR değerlerinin artmasına bağlı olarak özellikle NaCl uygulamasında artmıș, $\mathrm{NaHCO}_{3}$ tuz çeșidinin $\mathrm{EC}_{\mathrm{e}}$ 'e etki etmediği belirlenmiștir. Sulama uygulamalarında kullanılan suların tuz çeșidlerinin sudaki çözünürlüklerinin farklı olmasından dolayı sulama dönmelerinde istatistiksel farklılıklar tespit edilmiștir. Tuzların özellikle yüzeyde $(0-10 \mathrm{~cm})$ birikme gösterdiği ve yüzeyden alt derinliklere tuzların tașındığı belirlenmiștir. Çalıșma sonuçlarına göre $\mathrm{Na}^{+}$içeren $(\mathrm{NaCl}$ ve $\mathrm{NaHCO}_{3}$ gibi) tuzları ile uzun süren sulamalar yapıIması durumunda topraklardaki fiziko-kimyasal bazı özelliklerin değerlendirilmesinde sulama suyu kalitesi, tuz çeșidi, sulama mevsimi, sulama sıklığının ve toprak geçirgenliği gibi faktörlerin göz önünde bulundurulması gerekli olduğu tespit edilmiștir.

\section{KAYNAKLAR}

Abu-Alrub I, Marcum KB, Kabir N, Aran A, Hammadi MA (2018). Productivity and nutritional value of four forage grass cultivars compared to Rhodes grass irrigated with saline water. Australian Journal of Crop Science, 12 (02): 203-209.

Akalan I (1977). Toprak Olușu, Yapısı ve Özellikleri. A.Ü. Zir. Fak. Yayınları, No: 662. Ankara.

Al-Busaidi AS, Cookson P (2003). Salinity-pH relationships in calcareous soils. Agricultural and Marine Science, 8: 41-46.

Alsadon A, Sadder M, Wahb-Allah M (2013). Responsive gene screening and exploration of genotypes responses to salinity tolerance in tomato. Australian Journal of Crop Science, 7 (9): 1383- 1395.

Amezketa E (1999). Soil aggregate stability: a review Journal of Sustainable Agriculture, 14: 83-151.

Amit R, Yehouda E, Tamir G, Onn C, Naomi P, Avner A (2010). The role of rare rainstorms in the formation of calcic soil horizons on alluvial surfaces in extreme deserts. Quaternary Research, 74: 177-187.

Avcı S (2018). Farklı sulama yönetimi uygulamalarının lizimetre koșullarında drenaj suyu kalitesine, toprak tuzluluğuna ve yoncada (Medicago sativa) verime etkisi. Doktora tezi, Ankara Üniversitesi Fen Bilimleri Enstitüsü, Ankara.
Ayers RS, Westcot DW (1985). Water quality for agriculture (Vol. 29). Rome: Food and Agriculture Organization of the United Nations.

Bouaroudj S, Menad A, Bounamous A, Ali-Khodja $\mathrm{H}$, Gherib A, Weigel DE, Chenchouni H (2019). Assessment of water quality at the largest dam in Algeria (Beni Haroun Dam) and effects of irrigation on soil characteristics of agricultural lands. Chemosphere Journal, 219: 76-88.

Bouyoucos GJ (1951). A recalibration of hydrometer method for making mechanical analysis of soils. Agronomy Journal, 43: 434-438.

Bower CA, Reitmeir RF, Fireman M (1 952). Exchangeable cation analysis of saline and alkali soils. Soil Science, 73: 251261.

Costa JL, Aparicio VC (2015). Quality assessment of irrigation water under a combination of rain and irrigation. Agricultural Sciences Journal, 159: 299-306.

Çakır R, Gidișlioğlu A (1997). Düșük kaliteli sulama sularının vertisol toprakların bazı özelliklerine ve ayçiçeği bitkisinin vegatatif gelișmesine etkileri. VI. Tarımsal Tapılar ve Sulama Kongresi, Bursa.

Esechie HA (1994). Interaction of salinity and temperature on the germination of sorghum. Journal of Agronomy and Crop Science, 172: 194-199.

Felhendler R, Shainberg I, Frenkel H. (1974). Dispersion and the hydraulic conductivity of soils in mixed solutions. Trans Int Congr Soil Sci.

Frenkel H, Goertzen JO, Rhoades JD (1978). Effects of clay type and content exchangeable sodium percentage, and electrolyte concentration on clay dispersion and soil hydraulic conductivity. Soil Science Society of America Journal, Madison, 42:32-39.

Gupta RK, Bhumbla DK, Abrol IP (1984). Sodium-calcium exchange equilibria in soils as affected by calcium carbonate and organic matter. Soil Science, 138(2): 109-114.

Hasan HI, Battikhi AM, Orunfleh MM (2015). Impacts of Treated Wastewater Reuse on Some Soil Properties and Production of Gladiolus communis. Jordan Journal of Agricultural Sciences Journal, 11(4): 1103-1118.

Hassanli AM, Javan M, Saadat Y (2008). Reuse of municipal effluent with drip irrigation and evaluation the effect on soil properties in a semi-arid area. Environmental monitoring and Assessment, 144(1-3): 151-158.

Hazelton P, Murphy B (2016). Interpreting soil test results: What do all the numbers mean? : CSIRO publishing.

Kanber R, Ünlü M (2010). Tarımda Su ve Toprak Tuzluluğu. C..Ü. Ziraat Fakültesi Genel Yayın No: 281, Kitap Yayın No: A-87. Adana.

Karakoç B, Kale S (2016). Farklı Erirlikteki Tuz Cinslerine Sahip Sulama Suyu Tuz Düzeylerinin, Marul (Lactuca Sativa) Verimi Üzerine Etkileri. Süleyman Demirel Üniversitesi Ziraat Fakültesi Dergisi, 1(1): 1-7.

Kurunç A (2017). Sulama Suyu Kalitesi ve Tuzluluk, Tuzluluğun Bitkilere Etkisi, Akdeniz Üniversitesi Tarımsal Yapılar ve Sulama Bölümü Ders Notları. 
Li XB, Kang YH, Wan SO, Chen XL, Chu LL (2015). Reclamation of very heavy coastal saline soil using dripirrigation with saline water on salt-sensitive plants. Soil and Tillage Research Journal, 146: 159-173.

Li N, Kang Y, Li X, Wan S, Xu J (2019). Effect of the micro-sprinkler irrigation method with treated effluent on soil physical and chemical properties in sea reclamation land. Agricultural Water Management Journal, 213: 222-230.

Liu X, Feike T, Chen S, Shao L, Sun H, Zhang X (2016) Effects of saline irrigation on soil salt accumulation and grain yield in the winter wheat-summer maize double cropping system in the low plain of North China. Journal of Integrative Agriculture,

\section{5 (12): 2886-2898.}

Maas EV (1986). Salt Tolerance of Plants. Applied Agricultural Research, 1: 12-26.

Makoi JHJR, Verplancke H (2010). Effect of gypsum placement on the physical chemical properties of a saline sandy loam soil. Australian Journal of Crop Science, 4(7):556563.

Mancino CF, Pepper I.L (1992). Irrigation of turfgrass with secondary sewage effluent: Soil quality. Agronomy Journal, 84:650-654.

Meiri A, PlautZ( 1985). Crop Production and Management under Saline Conditions, Plant and Soil, 89:253-271.

Mostafazadeh-Fard B, Haydarpour M, Aghakhani A, Feizi $M$ (2007). Effects of irrigation water salinity and leaching on soil chemical properties in an arid region. nternational Journal of Biology, 9(3):466-469.

Munsuz, N, Çaycı G, Ok SS (2001). Toprak Islahı ve Düzenleyiciler Ankara Ünv. Zir. Fak. Yayınları, No: 1518, Yardımcı Ders Kitabı: 471.

Nelson DW, LE Sommers (1982). Total carbon, organic carbon, and organic matter. Methods of soil analysis. Part 2. Chemical and microbiological properties: pp. 539-579.

Özdemir N (1998). Toprak fiziği. OMÜ Yayınları, Ders Kitabı No: 30.

Pessoa LGM, dos Santos Freire MBG, dos Santos RL, Freire FJ, Miranda MFA, dos Santos PR (2019). Saline water irrigation in semiarid region: l-effects on soil chemical properties. Australian Journal of Crop Science, 13(7): 1169.

Pondkule RG, Jadhao SM (2020). Impact of irrigation on soil properties in Purnavalleyof Vidarbha region of Maharashtra. International Journal of Chemical Studies, (1): 2110-2114.

Pupisky H, Shainberg I ( 1979). Salt effects on the hydraulic conductivity of a sandy soil, Soil Science Society of America Journal, 43:429-433.

Qian Y, Lin Y (2019). Comparison of soil chemical properties prior to and five to eleven years after recycled water irrigation. Journal of Environmental Quality, 48(6): 1758-1765.

Rana L, Dhankhar R, Chhikara S (2010). Soil characteristics affected by long term application of sewage wastewater. International Journal of Environmental Research,4(3): 513-518.
Richards LA (1954). Diagnosis and improvement of saline and alkali solls, USD A Handbook No: 60.

Rhoades JD, Ingvalson RD (1969). Macroscopic swelling and hydraulic conductivity properties of four vermiculite soils. Soil Science Society of America Journal, 33: 364-369.

Rowell CHF, Mckay JM (1969).An acridid auditory interneurone. I. Functional connexions and responses to single sounds Journal of Experimental Biology, 51: 231-47.

Rusan MJM, Hinnawi S, Rousan L (2007). Long term effect of wastewater irrigation of forage crops on soil and plant quality parameters. Desalination, 215: 143-152.

Schipper LA, Williamson JC, Kettles HA, Speir TW I 1996). Impact of land-applied tertiary-treated effluent on soil biochemicalproperties. Journal of Environmental Quality, 25:1073-1077.

Shainberg I, Rhoades JD, Prather RJ (1981a). Effect of low electrolyte concentration on clay dispersion and hydraulic conductivity of a sodic soil. Soil Science Society of America Journal, 45: 273-277.

Shainberg I, Rhoades JD, Prather RJ (1981b). Effect of mineral weathering on clay dispersion and hydraulic conductivity of sodic soils. Soil Science Society of America Journal, 45: 287-291.

Shainberg I, Levy GJ (1992). Physical-chemical effects of salts upon infiltration and water movement in soils. In: Wagenet, R.J. (Ed.), Interacting Processes in Soil Science. Advances in soil Sciences, Lewis Publishers, Boca Raton, FL, pp. 38-93.

Sönmez B, Beyazgül M ( 2008). Türkiye'de Tuzlu ve Sodyumlu Toprakların Islahı ve Yönetimi, Sulama ve Tuzlanma Konferansı, 12-13 Haziran 2008, Șanlıurfa.

Sun JX, Kang YH, Wan SO, Hu W, Jiang SF, Zhang TB (2012). Soil salinity management with drip irrigation and its effects on soil hydraulic properties in north China coastal saline soils. Agricultural Water Management Journal, 115: 10-19.

Sreenivas C, Reddy CK (2008). Salinity-sodicity relationships of the Kalipatnam drainage pilot area, Godavari western delta, India. Irrigation and Drainage: The journal of the International Commission on Irrigation and Drainage, 57(5): 533-544.

Tan HK (1993). Soil Reaction. In Principles of Soil Chemistry, 2nd edn. Marcel Dekker: New York, 255-278.

Tarchouna LG, Merdy P, Raynaud M, Pfeifer HR, Lucas $Y(2010)$. Effects of long-term irrigation with treated wastewater. Part I: Evolution of soil physico-chemical properties. Applied Geochemistry, 25(11):1703-1710.

Tașan S, Demir Y (2019). Toprakların tuzluluk ve sodikliğinin alansal ve zamansal değișiminin jeoistatistiksel yöntemlerle değerlendirilmesi: Bafra ovası örneği. Anadolu Tarım Bilimleri Dergisi, 34(3): 336-350

Tunç T, Șahin $U$ (2015). The changes in the pHysical and hydraulic properties of a loamy soil under irrigation with simpler-reclaimed wastewaters. Agricultural Water Management Journal, 158:213-224. 
Ülgen N, Yurtsever N (1974). Türkiye Gübreler ve Gübreleme Rehberi. Toprak ve Gübre Araștırma Enstitüsü Müdürlüğü, Teknik Yayınlar No:28. Ankara.

Üzen N (2007). Güneydoğu Anadolu Bölgesi Koșullarında Yetiștirilen Kimi Pamuk Ceșitlerinin Farklı Seviyelerdeki Tuz Stresine Gösterdikleri Tepkilerin İncelenmesi Yüksek Lisans Tezi. Cukurova Üniversitesi Fen Bilimleri Enstitüsü, Adana.

Wang RS, Kang YH, Wan SO, Hu W, Liu SP, Liu SH (2011). Salt distribution and the growth of cotton under different drip irrigation regimes in a saline area. Agricultural Water Management Journal, 100:58-69.

Wang X, Yang J, Liu J, Yao R, Yu S (2015). Impact of irrigation volume and water salinity on winter wheat productivity and soil salinity distribution. Agricultural Water Management Journal, 149:44-54.
Yurtseven E, Güngör Y (1990). Değișik Tuzluluk Düzeylerindeki Sulama Sularının Toprak Tuzlulașmasına Etkisi. Turkish Journal of Agriculture and Forestry Journal, 14: 555-561.

Yurtseven E, Sönmez B (1996). Sulama Suyu Tuzluluğunun Domates Verimine ve Toprak Tuzluluğuna Etkisi. Turkish Journal of Agriculture and Forestry Journal, 20(1):27-33.

Yurtseven E, Öztürk HS, Avcı S, Altınok S, Selenay MF (2012). Farklı Sulama suyu kalitesi ve yıkama oranı uygulamalarında profil tuzluluğunun değișimi. Toprak Su Dergisi, $1(1): 38-46$. 